\title{
Retailscape: An exploration of the relevant dimensions and their impact on consumers' behavioral intentions
}

\author{
Makarand Upadhyaya \\ Hatem Mohamed EL-Shishini \\ Waleed A. Aziz
}

College of Business Administration, University of Bahrain, Bahrain

Vijayesh Kumar

College of Business, University of Buraimi, Al Buraimi Oman

\section{Keywords}

Servicescape, environmental dimensions, perceived quality, behavioral intentions

\begin{abstract}
Intangibility is a defining characteristic of services. The customer of a service offering is involved in an inexorable search for pre-purchase cues that can reduce his degree of perceived risk for the service that he or she intends to purchase. Servicescape, the environment in which a service process takes place, has a paramount influence in re-assuring the customer and eventually enabling him or her in comprehending the experiential outcomes of purchase and consumption. The paper investigates the impact of retailscape (retail servicescape) on behavioral intentions of customers in the retail industry. The servicescape framework in this paper is based on selected aspects of Bitner's (1992) servicescape framework and Wakefield and Blodgett's (1994) model.

Five servicescape dimensions have been identified, viz. ambient conditions, spatial layout, functionality, spatial signs, symbols and artifacts and cleanliness. The paper studies the impact of these dimensions on the perceived quality of the servicescape and on the shoppers' desire to stay in the retail store.

The research methodology comprises three stages:

- a literature review;

- a qualitative exploration consisting of in-depth interviews and focus groups; and

- A quantitative descriptive survey of consumers.

Factor Analysis is performed using SPSS 16. Multiple regression is employed to study the relationship between service dimensions and perceived service quality and perceived service quality and satisfaction and satisfaction and desire to stay. The study strongly supports that spatial layout and ambient conditions bear the strongest relationship with the perceived quality of the servicescape. These two dimensions make statistically unique contribution to the prediction of perceived servicescape quality. Results of regression reveal that satisfaction with the servicescape is positively influenced by perceived quality of the servicescape. Satisfaction and shoppers' desire to stay are positively related and the relationship is strong.
\end{abstract}

Corresponding author: Makarand Upadhyaya

Email addresses for corresponding author: makarandjaipur@gmail.com

First submission received: $18^{\text {th }}$ September 2017

Revised submission received: $9^{\text {th }}$ November 2017

Accepted: $9^{\text {th }}$ January 2018

Introduction

The effect of atmospherics, or physical design and decor elements, on consumers and workers is well recognized in the service industry, which is characterized by a dearth of tangibles. Service organizations cannot create a superior service experience without creating a superior physical surrounding, in which service is created and delivered. A well designed servicescape has a positive impact on buying behavior. Ambience and surroundings have a paramount influence on customers' evaluation of a service experience (Levitt, 1981). 


\section{Review of Literature}

Physical environment is inevitably a means of influencing behaviors and creating an image, especially for service businesses such as hotels, restaurants, professional offices, banks, retail stores, and hospitals (Baker 1987; Bitner 1986; Kotler 1973; Shostack 1977; Zeithaml, Parasuraman, and Berry 1985). Bitner and Bernard (1981) defined servicescape as "the environment in which the service is assembled and in which the seller and customer interact, combined with tangible commodities that facilitate performance or communication of the service". McComish and Quester et al. (2007), consider servicescape to be a group of physical environments of service setting which has an influential role on the consumer's buying experience. Services are characterized by simultaneity, that is, simultaneous production and consumption, and hence more often than not a consumer is in the service factory where ambience adds to or detracts from his total experience of the received service. Physical surroundings are, in general, more important inservice settings because customers as well as employees often experience the firm's facility. The lack of intangibility puts an absolute dependence on physical environment for gathering pre-purchase cues on the quality and credibility of the firm's offerings (Berry and Clark 1986; Shostack 1977). The physical environment especially abounds in such cues (Rapoport 1982) and exerts a profound influence in communicating the firm's image and purpose to its customers and prospects. Michaelle (1996) considered the service environment or servicescape as a composition of aesthetic design, functional design, and social elements. Ambient or aesthetic design elements are "intangible background conditions that tend to affect the senses and, in some cases, may have a relatively subconscious effect" on the customer. Bitner (1990) proposed that physical setting also influences customer's ultimate satisfaction with the service experience. Services typically require a direct interaction between customers and employees and hence the organization's environment should support the needs and preferences of both service employees and customers simultaneously. Employees too are influenced by a conducive physical setting and demonstrate higher productivity, morale, motivation and work place satisfaction (Becker 1981; Davis 1984; Wineman 1986). Servicescapes, though an important ingredient of the service offering, differ in its management and planning depending on the level of interaction that customers have with the facility. Bitner Servicescape is a model developed by Booms and Bitner to emphasize the impact of the physical environment in which a service process takes place.

The aim of the servicescapes model is to explain behavior of people within the service environment with a view to designing environments that accomplish organisational goals in terms of achieving desired behavioural responses. For consumers visiting a service or retail store, the service environment is the first aspect of the service that is perceived by the customer and it is at this stage that consumers are likely to form impressions of the level of service they will receive. Proposed a continuum where the left extreme represents a state of high customer involvement and the right extreme represents negligible customer involvement. For instance, in "self-service" organizations very few employees are present, and the customer activity is very high, to the extent that he is practically a co-producer. At the other extreme lie the fully automated services, that is, the "remote service" where there is little or no customer involvement in the servicescape and sometimes even little employee involvement too. Between the two extremes are positioned the "interpersonal services". In these organizations, both customers and employees are present and performing actions within the servicescape.

The relative level of involvement of customers and employees determines whose needs should be consulted in the design of the environment. In interpersonal servicescapes, special consideration must be given to the effects of the physical environment on the nature and quality of the social interaction between and among customers and employees (Bitner, 1992). Whether customers, employees, or both are present within the servicescape also determines the types of objectives a firm might expect to accomplish through use of its physical environment. In self-service settings, the creative use of physical design could support particular positioning and segmentation strategies and enhance specific marketing objectives, such as customer satisfaction and attraction. At the other extreme, for remote services, organizational objectives such as employee satisfaction, motivation, and operational efficiency could be the primary goals in physical setting design, because few customers would ever see or experience the firm's physical setting. For interpersonal services, both organizational and marketing objectives could potentially be targeted 
through careful design of the servicescape. Even marketing goals such as relationship building (Crosby, Evans, and Cowles 1990) could be influenced by the design of the physical setting.

\section{Servicescape Models}

Bitner's Model (1992)

Bitner (1992) proposed a framework for explaining what behaviors servicescape can influence and how and why the service environment should be planned to achieve the pertinent objectives that the organization has assumed for itself. Bitner's framework suggests that both employees and customers are impacted congnitively, emotionally and behaviorally by the servicescapes in which they deliver and receive services respectively. These internal responses to the environment influence the behavior of customers and employees and these behaviors in turn affect social interactions between and among customers and employees. The model shares striking similarities with other models (e.g., Mehrabian and Russell 1974), but it is unique because the Mehrabian and Russell model focuses on emotional responses only whereas Bitner's model encompasses cognitive and behavioral dimensions too.

\section{Wakefield and Blodgett (1994)}

Wakefield and Blodgett (1994) proposed a servicescape framework that has five environmental dimensions viz. layout accessibility, facility aesthetics, seating comfort, electronic equipment displays and facility cleanliness. These five dimensions impact on the perceived quality of the servicescape and consequently the satisfaction with servicescape. This in turn has a bearing on the patronage intentions and the desire to stay at the facility. Hence, the longer one spends in a facility, the greater the likelihood that the perceived quality of the servicescape will play an important role in determining satisfaction with the service. Physical surroundings thus play a role similar to a physical good's packaging in that it basically communicates an image of what is included in the service.

Figure 1

\section{Source:}

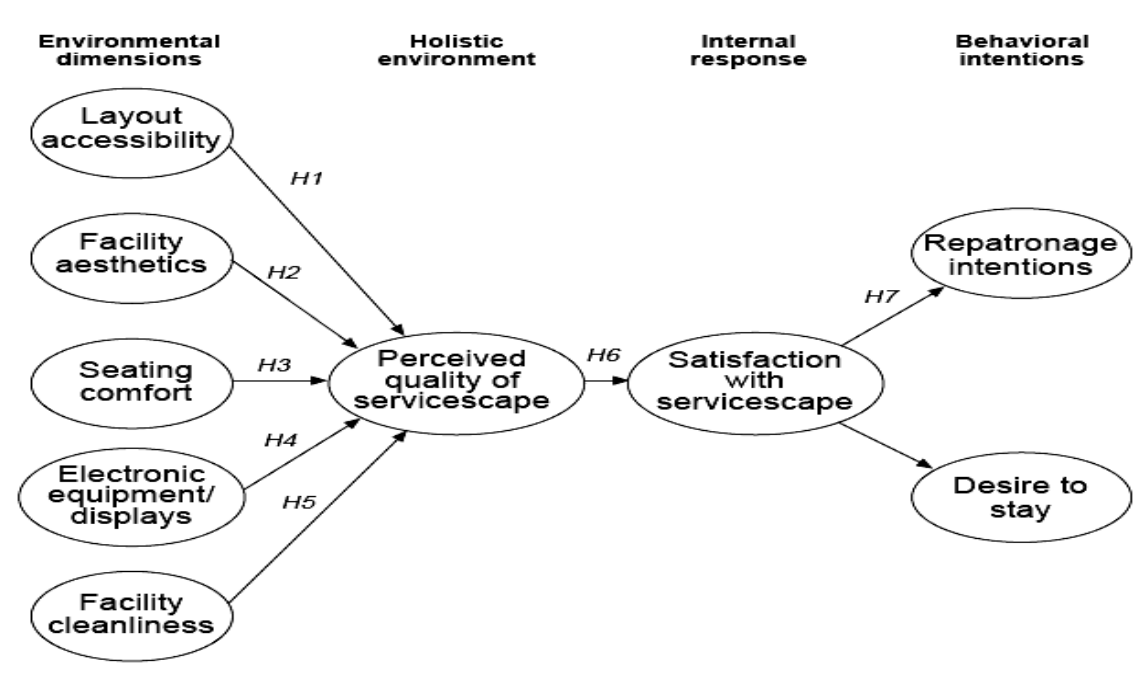

Wakefield, K.L. and Blogett, J.G. (1996), “The effect of the servicescape on customers' behavioral intentions in leisure service settings", Journal of Services Marketing, Vol.10 No.6, pp.46.

\section{Bitner's Model (1992)}

Bitner (1992) proposed a framework for explaining what behaviors servicescape can influence and how and why the service environment should be planned to achieve the pertinent objectives that the organization has assumed for itself. Bitner's framework suggests that both employees and customers are impacted congnitively, emotionally and behaviorally by the servicescapes in which they deliver and receive services respectively. These internal responses to the environment influence the behavior of customers and employees and these behaviors in turn affect social interactions between and among customers and employees. The model shares striking similarities with other models (e.g., Mehrabian and Russell 1974), but it is unique because the Mehrabian and Russell model focuses on emotional responses only whereas Bitner's model encompasses cognitive and behavioral dimensions too. 


\section{Dimensions of Servicescape}

Dimensions of servicescape include all the objective physical factors that can produce a possible approach effect for both customers and employees alike. There could be an infinite list of such factorslighting, color, signage, textures, quality of materials, style of furnishings, layout, wall decor, temperature, and so on. Review of literature as well as significant research in this field by Bitner (1982) suggests three important aspects of servicescape as (See Figure 2)

1) Ambient Conditions (e.g. temperature, air quality, noise, music, odor, etc.)

2) Spatial layout and functionality (e.g. layout, equipment, furnishings, etc.)

3) Signs, Symbols and Artifacts (e.g. signage, personal artifacts, style of décor, etc.) According to environmental psychologists, people respond to their environments in a comprehensive and holistic manner. That is, though individuals perceive discrete stimuli, it is the total configuration of stimuli that determines their responses to the environment (Bell, Fisher, and Loomis 1978; Holahan 1982; Ittelson et al. 1974). Hence, though the dimensions of the environment are defined independently here, it is important to recognize that they are perceived by employees and customers as a holistic pattern of interdependent stimuli.

\section{Ambient Conditions}

Several authors have identified ambient conditions as a factor that affects perceptions of and human responses to the environment (Darley and Gilbert 1985; Russell and Snodgrass 1987; Sundstrom and Sundstrom 1986). Ambient conditions affect the five senses and thus help in sensory branding of the service organization. Typically, ambient conditions include lighting, smell, temperature, noise and music. For example, in studies of restaurants and supermarkets, it has been illustrated that music tempo can affect pace of shopping, length of stay, and amount of money spent (Milliman 1982, 1986). Sometimes, these dimensions are not distinctly palpable, but yet have immense effect on customers and employees who spend a significant time at the service factory.

\section{Spatial layout and functionality}

Spatial layout refers to size, shape, arrangement and spatial relationships among machinery, equipments, and furnishings. Functionality refers to the ability of the same items to facilitate performance and the accomplishment of goals of the customer, as service encounter environments are functional environment. Spatial layout and functionality are essentially important for self-service organizations where the customer is almost a co-producer and hence needs to be facilitated in the accomplishment of his goals of visiting the service organization.

\section{Signs, Symbols and Artifacts}

Signs, symbols and artifacts are potent means of communicating the image of a service organization. Signages are explicit communicators and may include labels of departments, name plates, identity cards, directional material-arrows, and also rules of expected behavior-no smoking, danger zone, adults must accompany children, silence etc. Other elements in the environment, though not strong communicators, also convey a meaning and status. Quality of materials used in construction, artwork, presence of certificates and photographs on walls, floor coverings and personal objects displayed in the environment can all communicate symbolic meaning and create an overall aesthetic impression. Signs, symbols, and artifacts are particularly important in forming first impressions, for communicating new service concepts, for repositioning a service and in highly competitive industries where customers are looking for cues to differentiate the organization. 


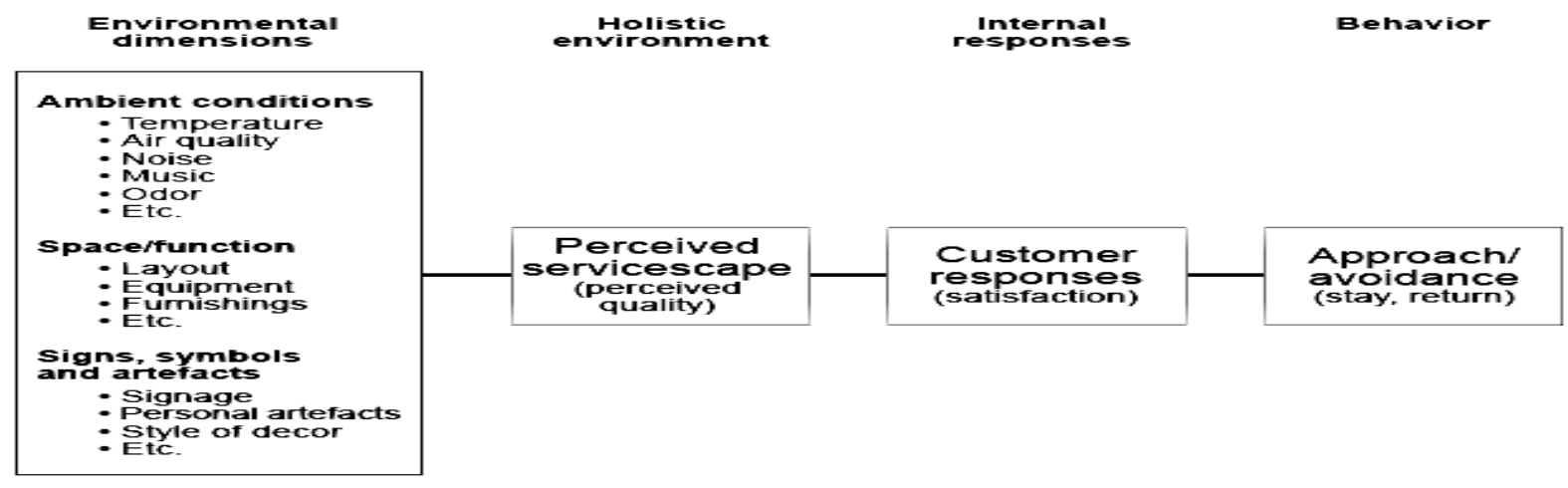

Figure 2-Servicescape Framework

Source: Adapted from Bitner's (1992) Framework for Understanding Environment-user Relationship in Service Organizations.

\section{Behavioral Responses to Servicescape Dimensions}

The dimensions of organization's servicescape influence important customer and employee behaviors. Mehrabian and Russell (1974) propose that individuals respond by exhibiting two general and contrasting forms of behavior-approach and avoidance. Approach behaviors include all positive responses towards a place-desire to stay, associate, affiliate, explore and work. Avoidance behaviors are just the opposite and include a desire not to stay, associate, affiliate, explore and work. In a study of consumers in retail environments, Donovan and Rossiter (1982) found that approach behaviors in a retail setting include a feeling of achievement by shopping, repatronage, expressions of commitment, attraction and friendliness toward others, spending money, spending time in browsing and exploration of the store. Milliman $(1982,1986)$ found that the tempo of background music can affect traffic flow and gross receipts in supermarket and restaurant settings. Each individual visits a retail outlet with a purpose and the physical setting of the outlet must help him in achieving what he had planned. For example, a shopper to a retail store must be able to locate the merchandize that he had planned to purchase, the signages should enable him to procure his material, the music, sound, acoustics, lighting and smell. should be emotionally encouraging to inspire him to stay for long. This is how a well-planned retail servicescape assists a shopper to accomplish the purpose for which he has visited the store. Obviously, retail stores strive to cultivate positive (approach) behaviors and deter negative (avoidance) behaviors and at the same time enable customers and employees to carry achieve their desired outcomes. Besides affecting individual behaviors, servicescapes act as facilitators in increasing the quality of interaction between employees and customers, most importantly in interpersonal services. Bennett and Bennett (1970) state that "all social interaction is affected by the physical container in which it occurs." This physical container is aptly the servicescape that affects the duration of interaction and actual progression of events. Forgas (1979) suggests that environmental variables such as propinquity, seating arrangements, size, and flexibility can define the possibilities and limits of social episodes, such as those between and among customers and employees.

One of the challenges in designing environments to enhance individual approach behaviors and encourage the appropriate social interactions is that optimal design for one person or group may not be the optimal design for others (Baker, Berry, and Parasuraman 1988). Similarly, an environment that is conducive to an employee's individual work needs may not enhance the employee's ability to converse and interact interpersonally with customers.

\section{Theoretical Framework}

The servicescape framework in this paper is based on selected aspects of Bitner's (1992) servicescape framework (see figure 2) with reference to Wakefield and Blodgett's (1994) model (see figure1) in studying the effect on customers' behavioral intentions in retail. Five servicescape factors applied to a retail store include (1) ambient conditions, (2) spatial layout, (3) functionality, (4) signs, 
symbols and artifacts, (5) cleanliness. The effects of these dimensions on perceived servicescape quality were examined. Based on this, it is hypothesized that:

H1: Ambient conditions affect the perceived quality of servicescape;

H2: Spatial layout affects perceived quality of servicescape;

H3: Functionality affects the perceived quality of servicescape;

H4: Spatial signs, symbols and artifacts affect the perceived quality of servicescape;

H5: Cleanliness affects the perceived quality of servicescape;

H6: The perceived quality of servicescape has a positive effect on satisfaction with the servicescape;

H7: Satisfaction with the servicescape has a positive effect on the shoppers' desire to stay in the retail store;

The hypothesized model is shown in Figure 3

Figure 3-Hypothesized Model

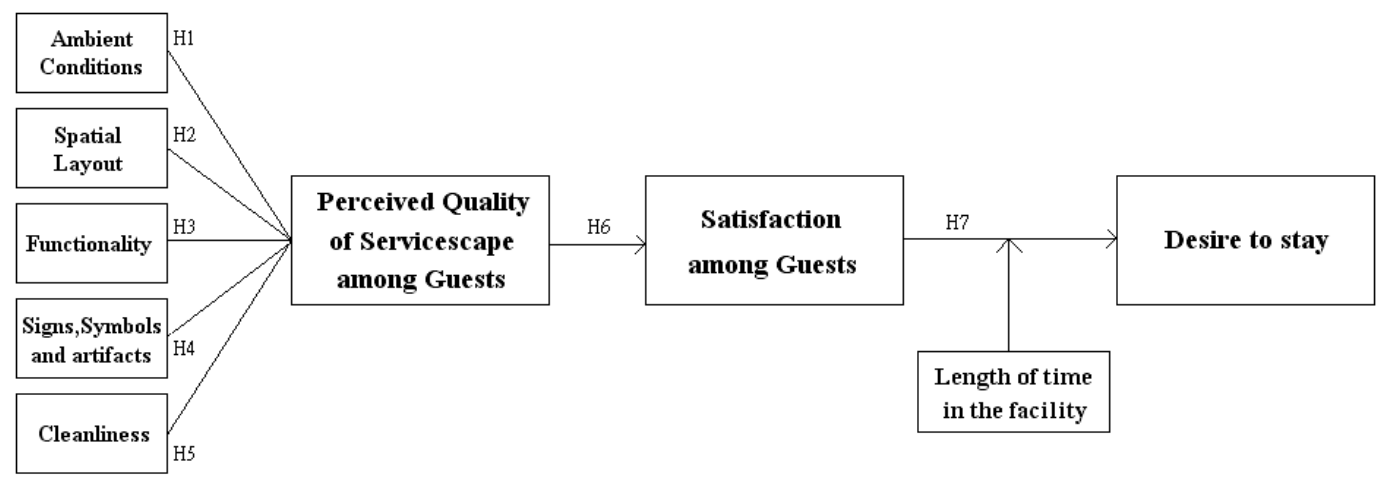

Source: Developed for research

\section{Research Design \\ Methodology}

The research methodology applied in this study consisted of three stages:

- a literature review;

- a qualitative exploration consisting of in-depth interviews and focus groups; and

- a quantitative descriptive survey of consumers.

\section{Preliminary Study-Exploratory Stage of research}

Since there is a dearth of research on retail servicescape, especially in India, an exploratory research should first be used (Cooper and Schindler 2001; Zikmund 1997) to identify relevant issues, to gather ideas and insights and then to develop the hypotheses for later testing (Churchill and Iacobucci 2002). This study is a preliminary step to gain a more rigorous and adequate understanding of issues related to retail servicescape in the explanatory stage (Zikmund 1997). This allowed the development of a preliminary model of the impact of a various variables on consumers' attitudes toward retail servicescape.

\section{Participants}

300 participants were randomly selected for the study. The respondents were essentially consumers of a selected retail stores in Jaipur. Each respondent was administered a structured questionnaire comprising 30 variables. Sampling procedure employed was Convenience Sampling (Nonprobability Sampling)

\section{Measurement Instrument}

A structured questionnaire was developed based on the literature review and exploratory studies- in-depth interviews and focus groups. The design and administration of the questionnaire 
followed six steps which were adapted from Churchill (1979) Frazer and Lawley (2000) and Kinnear and Taylor (1996). The questionnaire consisted of 30-items to be rated on a 10-point Likert-type scale, ranging from 1 (probably very untrue)-10 (probably very true).

\section{Data Analysis}

A Factor Analysis was performed on 30 variables using SPSS 16.

\section{Basic Assumptions}

Two statistics on the SPSS output that permit us to look at some of the basic assumptions.

- Kaiser-Meyer-Olkin Measure of sampling adequacy

- Bartlett's Test of sphericity

\section{Kaiser-Meyer-Olkin Measure of sampling adequacy}

This measure generally indicates whether or not the variables can be grouped into a smaller set of underlying factors. It is a measure of whether the distribution of values is adequate for conducting factor analysis. A measure $>.9$ is marvelous, $>8$ is meritorious, $>.7$ is middling, $>.6$ is mediocre, $>.4$ is miserable and $<.4$ are unacceptable. Thus, high values (close to 1.0) generally indicate that a factor analysis may be useful with your data. If the value is less than .40 , the results of the factor analysis probably will not be very useful.

\section{Bartlett's Test of sphericity}

This is a measure of the multivariate normality of the set of distributions. It also tests whether the correlation matrix is an identity matrix because factor analysis would be meaningless with an identity matrix. A significance value of $<.4$ indicates that these data do NOT produce an identity matrix (or differ significantly from identity) and are thus approximately multivariate normal and acceptable for factor analysis.

In the study, Kaiser-Meyer-Olkin measure for sampling adequacy yielded a value of .83. Bartlett's Test of Sphericity gave a value of .03 .

Table 1

\begin{tabular}{|l|l|}
\hline Kaiser-Meyer-Olkin measure of Sampling Adequacy & 0.83 \\
\hline Bartlett's Test of Sphericity & 0.03 \\
\hline
\end{tabular}

Both the measures indicate that the sample of the study reported here was adequate. So, clearly our data support the use of factor analysis and suggest that the data may be grouped into a smaller set of underlying factors.

\section{Factor Analysis}

Using Kaiser's criterion, 6 components with eigen value of 1 or more are selected. These 6 components account for $74.035 \%$ of the total variance. Air Quality, with loadings to 2 factors greater than 0.5 , is considered as cross-loaded and were therefore deleted. Of all the 30 statements in the questionnaire, 28 statements with factor loadings greater than 0.5 are selected for subsequent analysis.

Each of the items in for the 6 factors extracted is presented in Table2, with their respective loadings and mean scores. Factor means indicates respondents' attitude towards different dimensions of servicescape. As shown in Table 2, the five items in descending order of means score were as follows:

Spatial Layout (5.34), Signages (5.05), Ambient Conditions (4.96), Cleanliness (4.60), Facilities and artifacts (4.34) and Functionality (3.78)

Factor 1, Ambient Conditions, consisted of six items (alpha $=0.890$ ) and explained $47.894 \%$ of the variance. The mean score is 5.05, which is the second highest score. This factor reveals whether the retail store has pleasant lighting (4.98), appropriate background music and sound (5.20), appropriate temperature (5.34), pleasant odor (4.58), and overall comfortable ambient conditions (5.24), and adequate lighting (4.96).

Factor 2, Cleanliness, consisted of six items (alpha $=0.921)$ and explained $7.106 \%$ of the variance. The mean score is 4.60 , which is the fourth highest score. The six items are: overall very clean facility 
(4.58), clean walkways and exits (4.49), clean food zone (4.19), clean aisles (4.60), dust free furniture and fixtures (4.86) and products neatly arranged and displayed (4.92).

Factor 3, Signage, consisted of four items (alpha $=0.948$ ) and explained $5.955 \%$ of the variance. The mean score is 4.96, which is the third highest score among the six dimensions. These four items are related to the signage in the facility, namely, signage helps in locating merchandise (5.10), signage is big and distinct (5.02), sufficient signages (5.00) and signages are easy to comprehend (4.72).

Factor 4, Spatial Layout, consisted of four items (alpha=0.911) and explained $5.281 \%$ of the variance. It is the most satisfactory factor. The mean score is 5.34, which is the highest score among the six dimensions. It measures whether the store has a good parking (5.43), good interiors (5.27) and customer friendly layout (5.54) in the facility, as well as its aisles for easy movement of shoppers (5.11).

Factor 5, Facilities and Artifacts consisted of five items (alpha=0.855) and explained $4.003 \%$ of the variance. The mean score is 4.34 , which is the fifth highest score. The five items are: clean washrooms (3.94), sufficient drinking water fountains (4.59), aesthetically decorated facility (4.55), adequate seating space (4.15) and availability of kidzone (4.71).

Factor 6, Functionality, consisted of 3 items (alpha $=0.769$ ) and explained $3.796 \%$ of the variance. The mean score of 3.78 is the lowest among the six dimensions which is the least satisfactory factor. The three items are: high performance electronic equipments (3.56), fast billing (3.32) and fast location of needed merchandise. (4.45).

Table 2- Factor Extraction for Servicescape

\begin{tabular}{|c|c|c|c|c|}
\hline No. & Factors & Loading & Mean & Factor Mean \\
\hline & FACTOR 1 AMBIENT CONDITIONS & & & \\
\hline & The facility has pleasant lighting & 0.770 & 4.98 & \\
\hline & The background music/sound is pleasant & 0.760 & 5.20 & \\
\hline & The temperature in the facility is appropriate & 0.743 & 5.34 & $5.05(\mathrm{II})$ \\
\hline & The lighting is adequate & 0.739 & 4.96 & \\
\hline & The facility has a pleasant odor & 0.656 & 4.58 & \\
\hline & The overall ambient conditions make a comfortable stay & 0.635 & 5.24 & \\
\hline & FACTOR 2 CLEANLINESS & & & \\
\hline & The facility is overall very clean & 0.828 & 4.58 & \\
\hline & The walkways and exits are clean & 0.822 & 4.49 & \\
\hline & The food zone is clean & 0.803 & 4.19 & \\
\hline & The aisles are clean & 0.632 & 4.60 & 4.60 (IV) \\
\hline & The furniture and fixtures are dust free & 0.623 & 4.86 & \\
\hline & The products are neatly arranged and displayed & 0.586 & 4.92 & \\
\hline & FACTOR 3 SIGNAGES & & & \\
\hline & The signages help in locating merchandise & 0.737 & 5.10 & \\
\hline & The signage is adequately big and distinct & 0.736 & 5.02 & 4.96 (III) \\
\hline & There are sufficient signages in the facility & 0.710 & 5.00 & \\
\hline & The signages in the facility are easy to comprehend & 0.692 & 4.72 & \\
\hline & FACTOR 4 SPATIAL LAYOUT & & & \\
\hline & Facility layout has a good parking & .821 & 5.43 & \\
\hline & Facility has good interiors & .745 & 5.27 & $5.34(\mathrm{I})$ \\
\hline & Facility has a customer friendly layout & .733 & 5.54 & \\
\hline & $\begin{array}{l}\text { Facility layout has aisles to facilitate easy movement of } \\
\text { shoppers }\end{array}$ & .634 & 5.11 & \\
\hline & FACTOR 5 FACILITIES AND ARTIFACTS & & & \\
\hline & Facility has clean washrooms & 0.803 & 3.94 & \\
\hline & Facility has sufficient drinking water fountains & 0.633 & 4.59 & \\
\hline & Facility is aesthetically decorated & 0.576 & 4.55 & \\
\hline & Facility has adequate seating space & 0.564 & 4.15 & $4.34(\mathrm{~V})$ \\
\hline
\end{tabular}




\begin{tabular}{|l|l|l|l|l|}
\hline & Facility has a kid zone with babysitting service & 0.502 & 4.71 & \\
\hline & & & & \\
\hline & FACTOR 6 FUNCTIONALITY & & & \\
\hline & Facility offers high performing electronic equipments & 0.817 & 3.56 & $3.78(\mathrm{VI})$ \\
\hline & Equipments provide for fast billing & 0.797 & 3.32 & \\
\hline & Technology enables a fast location of needed merchandise & 0.554 & 4.45 & \\
\hline
\end{tabular}

Table 3-Total Variance Explained

\begin{tabular}{|c|c|c|c|c|c|c|}
\hline \multirow{2}{*}{ Component } & \multicolumn{3}{|c|}{ Initial Eigenvalues } & \multicolumn{3}{|c|}{ Extraction Sums of Squared Loadings } \\
\hline & Total & $\%$ of Variance & Cumulative \% & Total & $\%$ of Variance & Cumulative \% \\
\hline 1 & 14.368 & 47.894 & 47.894 & 14.368 & 47.894 & 47.894 \\
\hline 2 & 2.312 & 7.106 & 55.000 & 2.312 & 7.106 & 55.000 \\
\hline 3 & 1.787 & 5.955 & 60.955 & 1.787 & 5.955 & 60.955 \\
\hline 4 & 1.584 & 5.281 & 66.236 & 1.584 & 5.281 & 66.236 \\
\hline 5 & 1.201 & 4.003 & 70.239 & 1.201 & 4.003 & 70.239 \\
\hline 6 & 1.139 & 3.796 & 74.035 & 1.139 & 3.796 & 74.035 \\
\hline 7 & .855 & 2.849 & 76.884 & & & \\
\hline 8 & .780 & 2.598 & 79.482 & & & \\
\hline 9 & .673 & 2.244 & 81.727 & & & \\
\hline 10 & .629 & 2.097 & 83.824 & & & \\
\hline 11 & .596 & 1.986 & 85.810 & & & \\
\hline 12 & .486 & 1.620 & 87.431 & & & \\
\hline 13 & .473 & 1.577 & 89.008 & & & \\
\hline 14 & .407 & 1.358 & 90.366 & & & \\
\hline 15 & .383 & 1.276 & 91.642 & & & \\
\hline 16 & .347 & 1.157 & 92.799 & & & \\
\hline 17 & .308 & 1.025 & 93.824 & & & \\
\hline 18 & .267 & .891 & 94.715 & & & \\
\hline 19 & .244 & .813 & 95.528 & & & \\
\hline 20 & .234 & .778 & 96.306 & & & \\
\hline 21 & .188 & .627 & 96.934 & & & \\
\hline 22 & .167 & .558 & 97.491 & & & \\
\hline 23 & .152 & .506 & 97.998 & & & \\
\hline 24 & .131 & .437 & 98.435 & & & \\
\hline 25 & .112 & .374 & 98.809 & & & \\
\hline 26 & .101 & .336 & 99.145 & & & \\
\hline 27 & .091 & .304 & 99.449 & & & \\
\hline 28 & .080 & .265 & 99.714 & & & \\
\hline 29 & .068 & .226 & 99.940 & & & \\
\hline 30 & .018 & .060 & 100.000 & & & \\
\hline
\end{tabular}

Extraction Method: Principal Component Analysis

Table 4-Rotated Component Matrix

\begin{tabular}{|l|l|l|l|l|l|l|}
\hline & 1 & 2 & 3 & 4 & 5 & 6 \\
\hline A_Pleasant Lighting & 0.770 & & & & & \\
A_Background Music and Sound & 0.760 & .317 & .345 & & & \\
A_Temperature & 0.743 & & .341 & & & \\
A_Adequate Lighting & 0.739 & & .325 & & & \\
A_Pleasant Odor & 0.656 & & & & & \\
A_Air Quality & 0.635 & & & & .509 & \\
A_Overall & .544 & & & .331 & .396 & \\
C_Overall & .302 & 0.828 & & & & \\
C_Walkways and Exits & & 0.822 & & & & \\
C_Foodzone & & 0.803 & & & .353 & \\
C_Aisles & .314 & 0.632 & & .305 & & \\
C_Furnitures and Fixtures & & 0.586 & .434 & .337 & & \\
C_Product Displays & .343 & & 0.737 & & & \\
S_Ability to help in locating & & & & & \\
\hline
\end{tabular}




\begin{tabular}{|c|c|c|c|c|c|c|}
\hline & 1 & 2 & 3 & 4 & 5 & 6 \\
\hline S_Big and Distinct & & & 0.736 & & & \\
\hline S_Sufficient Signages & & & 0.710 & & & \\
\hline S_Easy to comprehend & .307 & .316 & 0.692 & & & \\
\hline SL_parking & & & & .821 & & \\
\hline SL_interiors & & & & .745 & & \\
\hline SL_customer friendly & .316 & & & .733 & & \\
\hline SL_easy traffic & .311 & .405 & & .634 & & \\
\hline F1_wash rooms & & & & & 0.803 & \\
\hline F1_drinking water & & & .423 & & 0.633 & \\
\hline F1_decorated & & & .455 & & 0.576 & \\
\hline F1_seating space & & .351 & & & 0.564 & \\
\hline F1_kidzone & .303 & & .318 & .346 & 0.502 & \\
\hline F1_smoking zone & & & .307 & & .497 & .325 \\
\hline F2_equipments & & & & & & 0.817 \\
\hline F2_fast billing & & & & & & 0.797 \\
\hline F2_ location friendly & & .304 & .393 & & & 0.554 \\
\hline
\end{tabular}

Extraction Method: Principal Component Analysis

Rotation Method: Varimax with Kaiser Normalization, Rotation converged in 9 iterations

Table 5-Reliability Test

Reliability test was applied to each construct in order to verify their reliability for further analysis. A measure of $>.7$ for all the dimensions (Table 5) make them reliable and internally consistent and thus eligible for further analysis.

\begin{tabular}{|l|l|l|}
\hline Component & Cronbach's Alpha & No. of items \\
\hline Ambient Conditions & .890 & 6 \\
\hline Cleanliness & .921 & 6 \\
\hline Signages & .948 & 4 \\
\hline Spatial Layout & .911 & 4 \\
\hline Facilities and Artifacts & .855 & 5 \\
\hline Functionality & .769 & 3 \\
\hline
\end{tabular}

\section{Multiple Regression}

The relationship among the six servicescape dimensions, perceived servicescape quality, satisfaction and desire to stay was analyzed by standard multiple regression.

\section{Relationship between Servicescape Dimensions and Perceived Quality}

The six servicescape dimensions explained $62.7 \%$ of the total variance in the dependent variable of overall perceived servicescape quality (Adjusted $\mathrm{R}$ Square $=0.627$ ). Thus, the relationship between servicescape dimensions and perceived quality is strong. To compare the contribution of each servicescape dimensions in forming customers' perceived servicescape quality, we refer to the Standardized Beta Coefficient. As shown in Table 6 below, the largest beta value is 0.362 , which is for Layout, which is closely followed by Ambient conditions (Beta $=0.353$ ). It shows that Layout and Ambient conditions have strongest relationships with perceived quality of servicescape. Moreover, among the 6 dimensions, only Layout (Sig. $=0.000$ ) and Ambient conditions (Sig. $=0.000$ ) were significant (Sig. <0.05), indicating that these 2 dimensions are making statistically unique contribution to the prediction of perceived servicescape quality. Therefore, only H1 and H2 are supported. 
Table 6-Relationship among Six Servicescape Dimensions and Perceived Servicescape Quality

\begin{tabular}{|l|l|l|l|}
\hline Dimensions & B & Beta & Sig. \\
\hline Functionality & 0.116 & 0.105 & 0.126 \\
\hline Layout & 0.336 & 0.362 & $0.000^{*}$ \\
\hline Signage & 0.115 & 0.128 & 0.101 \\
\hline Ambient Conditions & 0.382 & 0.353 & $0.000^{*}$ \\
\hline General facilities and artifacts & -0.109 & -0.113 & 0.117 \\
\hline Cleanliness & 0.087 & 0.103 & 0.061 \\
\hline Adjusted R Square $=0.627$ & & & ${ }^{*} \mathrm{p}<0.050$ \\
\hline
\end{tabular}

\section{Relationship between Perceived Quality and Satisfaction}

The result of regression reveals that satisfaction with the servicescape is positively influenced by perceived quality $($ Beta $=0.848$, Sig. $=0.000) .71 .7 \%$ of the total variance in visitors' satisfaction can be explained by their perceived quality (Adjusted R Square $=0.717$ ). H6 is supported.

Table 7 a-Model Summary ${ }^{b}$

\begin{tabular}{|l|l|l|l|l|}
\hline Model & R & R Square & Adjusted R Square & Std. Error of Estimate \\
\hline 1 & $.848^{\mathrm{a}}$ & .719 & .717 & .60779 \\
\hline
\end{tabular}

a. Predictors: (Constant), Perceived Quality

b. Dependent Variable: Satisfaction

Table 7b-ANOVA $b$

\begin{tabular}{|l|l|l|l|l|l|}
\hline Model & Sum of Squares & $\mathrm{df}$ & Mean Square & F & Sig. \\
\hline 1 Regression & 164.402 & 1 & 164.402 & 445.036 & $.000^{\mathrm{a}}$ \\
Residual & 64.278 & 174 & .369 & & \\
Total & 228.680 & 175 & & & \\
\hline
\end{tabular}

a. Predictors: (Constant), Perceived Quality

b. Dependent Variable: Satisfaction

\begin{tabular}{|l|lc|l|l|l|}
\hline $\begin{array}{l}\text { Table 7c-Coefficients } \\
\text { (a)Model }\end{array}$ & $\begin{array}{l}\text { Unstandardized } \\
\text { Coefficients } \\
\text { B }\end{array}$ & $\begin{array}{l}\text { Standardized } \\
\text { Coefficients } \\
\text { Beta }\end{array}$ & T & Sig. \\
\hline $\begin{array}{l}\text { 1(Constant) } \\
\text { Perceived Quality }\end{array}$ & .537 & .217 & & 2.470 & .014 \\
\hline
\end{tabular}

a Dependent Variable: Satisfaction.

\section{Relationship between satisfaction and desire to stay}

In testing H7, the predictive power of satisfaction in desire to stay, the Standardized Beta Coefficient was found to be 0.835 (Sig. $=0.000$ ), indicating that satisfaction and desire to stay are positively related and the relationship is strong. H7 is therefore supported. With Adjusted R Square of 0.695, satisfaction explained $69.5 \%$ of visitors' desire to stay longer.

Table 8a-Model Summary ${ }^{\mathrm{b}}$

\begin{tabular}{|l|l|l|l|l|}
\hline Model & $\mathrm{R}$ & R Square & Adjusted R Square & $\begin{array}{l}\text { Std. Error of the } \\
\text { Estimate }\end{array}$ \\
\hline 1 & $.835^{\mathrm{a}}$ & .696 & .695 & .62590 \\
\hline
\end{tabular}

a. Predictors: (Constant), Satisfaction

b. Dependent Variable: Desire to Stay

Table 8b-ANOVA b

\begin{tabular}{|l|l|l|l|l|l|}
\hline Model & Sum of Squares & df & Mean Square & F & Sig. \\
\hline 1 Regression & 156.381 & 1 & 156.381 & 399.190 & $.000^{\mathrm{a}}$ \\
Residual & 68.164 & 174 & .392 & & \\
Total & 224.544 & 175 & & & \\
\hline
\end{tabular}


The study applies the one-way ANOVA to identify the difference in variance between layout and and cleanliness.

a. Predictors: (Constant), Satisfaction

b. Dependent Variable: Desire to Stay

Table 8c-Coefficients (a)

\begin{tabular}{|l|l|l|l|l|l|}
\hline \multirow{2}{*}{ Model } & \multicolumn{2}{|l|}{$\begin{array}{l}\text { Unstandardized } \\
\text { Coefficients }\end{array}$} & $\begin{array}{l}\text { Standardized } \\
\text { Coefficients } \\
\text { Beta }\end{array}$ & $\mathrm{t}$ & Sig. \\
\cline { 2 - 3 } & $\mathrm{B}$ & Std. Error & & \\
\hline 1(Constant) & .584 & .213 & & 2.742 & .007 \\
Satisfaction & .827 & .041 & .835 & 19.980 & .000 \\
\hline
\end{tabular}

a Dependent Variable: Desire to Stay

\section{Conclusions and Recommendations}

Having run factor analysis, it was observed that the five dimensions chosen in the original model are amenable to being split into six, as signages stood out quite conspicuously from its original dimension of signs, symbols and artifacts. The six dimensions are ranked as follows (in descending order of ranking)

1. Spatial Layout

2. Ambient Conditions

3. Signages

4. Cleanliness

5. Facilities and Artifacts

6. Functionality

The store needs to make significant investment in increasing its functionality. The facility should offer high performing equipments that enable fast billing and fast location of needed merchandise. Facilities are artifacts need to be improved, with an urgent provision of clean wash rooms. Mean score on this item (3.94) is much less than the factor means (4.34). The study strongly supports that spatial layout and ambient conditions bear the strongest relationship with the perceived quality of the servicescape. These two dimensions make statistically unique contribution to the prediction of perceived servicescape quality. Results of regression reveal that satisfaction with the servicescape is positively influenced by perceived quality of the servicescape. Satisfaction and shoppers' desire to stay are positively related and the relationship is strong. The servicescape thus encourages the target customers to enter the service environment in the first place, and to retain them subsequently. Well-designed servicescapes thus provide substantial tangible cues for re-assuring, facilitating purchase and ensuring repeat business.

\section{References}

Baker, Julie (1987), "The Role of the Environment in Marketing Services: The Consumer Perspective," in The Services Challenge: Integrating for Competitive Advantage, John A. Czepiel, Carole A. Congram, and James Shanahan, eds. Chicago: American Marketing Association, 79-84.

Baker, Julie Leonard L. Berry, and A. Parasuraman (1988), "The Marketing Impact of Branch Facility Design," Journal of Retail Banking, 10 (2), 33-42. Barker, Ro

Becker, Franklin D. (1977), Housing Messages. Stroudsburg, PA: Dowden, Hutchinson \& Ross, Inc.

Bell, Paul, J. D. Fisher, and R. J. Loomis (1978), Environmental Psychology. Philadelphia: W. B. Saunders Co.

Bennett, David J. and Judith D. Bennett (1970), "Making the Scene," in Social Psychology Through Symbolic Interactionism, G. Stone and H. Farberman, eds. Waltham, MA: Ginn-Blaisdell, 190-6.

Berry, Leonard L. and Terry Clark (1986), "Four Ways to Make Services More Tangible," Business (October-December), 53-4.

Bitner (1990), "Evaluating Service Encounters: The Effects of Physical Surroundings and Employee Responses,"Journal of Marketing, 54 (April), 69-82.

Bitner (1992), " Servicescapes: The Impact of Physical Surroundings on Customers and Employees," Journal of Marketing, 56 (April), 57-71.

Bitner, Mary Jo (1986), "Consumer Responses to the Physical Environment in Service Settings," in Creativity in Services Marketing, M. Venkatesan, Diane M. Schmalensee, and Claudia Marshall, eds. Chicago: American Marketing Association, 89-93.

Booms Bernard H and Mary Jo Bitner (1981), "Marketing Strategies and Organization Structures for Service Firms", in Marketing of Services, (Eds.), American Marketing Association, Virtual Servicescapes, Chicago, p. 26. 
Churchill, G. (1979), "A paradigm for developing better measures of marketing constructs", Journal of Marketing Research, vol. 16, February, pp. 64-73.

Churchill, G. A. Jr. \& Iacobucci D (2002), Marketing Research: Methodological foundations, South-Western, Ohio.

Cooper, D. R. \& Schindler, P.S. (2001), Business Research Methods, Seventh edition, McGraw Hill, Singapore.

Crosby, Lawrence A., Kenneth R. Evans, and Deborah Cowles (1990), "Relationship Quality in Services Selling: An Interpersonal Influence Perspective," Journal of Marketing, 54 (July), 68-81.

Darley, John M. and Daniel T. Gilbert (1985), "Social Psychological Aspects of Environmental Psychology," in Handbook of Social Psychology, 3rd ed.. Vol. II, Gardner Lindzey and Elliot Aronson, eds. New York: Random House Inc., 949-91.

Davis, Tim R. V. (1984), "The Influence of the Physical Environment in Offices," Academy of Management Review 9 (2), 271-83.

Donovan, Robert and John Rossiter (1982), "Store Atmosphere: An Environmental Psychology Approach," Journal of Retailing, 58 (Spring), 34-57.

Forgas, Joseph P. (1979), Social Episodes. London: Academic Press, Inc.

Frazer, L. \& Lawley, M. (2000), Questionnaire Design and Administration: a practical guide, John Wiley \& Sons Australia, Ltd., Singapore.

Holahan, Charles J. (1982), Environmental Psychology. New York: Random House, Inc.

Ittelson, William H., Harold M. Proshansky, Leanne G. Rivlin, and Gary H. Winkel (1974), An Introduction to Environmental Psychology. New York: Holt, Rinehart and Winston, Inc.

Kinnear, T. C. \& Taylor, J. R. (1996), Marketing Research: An applied approach, Fifth edition, McGraw Hill, New York.

Kotler, Phillip (1973), "Atmospherics as a Marketing Tool, "Journal of Retailing, 49 (4), 48-64.

Levitt T (1981), “Marketing Intangible Products and Product Intangibles”, Harvard Business Review, Vol. 59, No. 3, pp. 94-102.

McComish M and Quester P G (2005), “Consumers' Affective Responses to the Retail servicescape: A Spatial and Temporal Perspective”, ANZMAC 2005 Conference: Retailing, Distribution Channels and Supply Chain Management, The University of Adelaide.

Mehrabian, Albert and James A. Russell (1974), An Approach to Environmental Psychology. Cambridge, MA: Massachusetts Institute of Technology.

Michaelle Cameron (1996), "The Effects of the Service Environment on Affect and Consumer Perception of Waiting Time: An Integrative Review and Research Propositions", Journal of the Academy of Marketing Science, Vol. 24, No. 4, pp. 338-349.

Milliman, Ronald (1982), "Using Background Music to Affect the Behavior of Supermarket Shoppers," Journal of Marketing, 46 (Summer), 86-91.

Milliman, Ronald (1986), "The Influence of Background Music on the Behavior of Restaurant Patrons," Journal of Consumer Research, 13 (September), 286-9.

Rapoport, Amos (1982), The Meaning of the Built Environment. Beverly Hills, CA: Sage Publications, Inc.

Russel and Jacalyn Snodgrass (1987), "Emotion and the Environment," in Handbook of Environmental Psychology, Vol. 1, Daniel Stokols and Irwin Altman, eds. New York: John Wiley \& Sons, Inc., 245-81.

Shostack, G. Lynn (1977), "Breaking Free from Product Marketing," Journal of Marketing, 41 (April), 73-80.

Sundstrom and Mary Graehl Sundstrom (1986), Work Places. Cambridge, UK: Camfindzeybridge University Press.

Wakefield, K.L. and Blodgett, J.G. (1994)," The importance of servicescapes in leisure service settings", Journal of Services Marketing, Vol. 8, No. 3, pp.66-76.

Wineman, Jean D. (1986), Behavioral Issues in Office Design. New York: Van Nostrand Reinhold Co.

Zeithaml, A. Parasuraman, and Leonard L. Berry (1985), "Problems and Strategies in Services Marketing," Journal of Marketing, 49 (Spring), 33-46.

Zikmund, W. G. (1997), Business Research Methods, Fourth edition, Dryden Press, New York. 